\title{
Degradation of transgenic DNA from genetically modified soya and maize in human intestinal simulations
}

\author{
Susana M. Martín-Orúe ${ }^{1}$, Anthony G. O’Donnell ${ }^{2}$, Joaquin Ariño ${ }^{3}$, Trudy Netherwood ${ }^{1}$, \\ Harry J. Gilbert ${ }^{1}$ and John C. Mathers ${ }^{1 *}$ \\ ${ }^{1}$ Human Nutrition Research Centre, Department of Biological and Nutritional Sciences, University of Newcastle upon Tyne, \\ Newcastle upon Tyne NE1 7RU, UK \\ ${ }^{2}$ Department of Agricultural and Environmental Sciences, University of Newcastle upon Tyne, Newcastle upon Tyne \\ $N E 17 R U, U K$ \\ ${ }^{3}$ Departament de Bioquímica i Biologia Molecular \& Servei de Seqüenciació de DNA, Universitat \\ Autonoma de Barcelona, Spain
}

(Received 2 July 2001 - Revised 7 January 2002 - Accepted 3 February 2002)

\begin{abstract}
The inclusion of genetically modified (GM) foods in the human diet has caused considerable debate. There is concern that the transfer of plant-derived transgenes to the resident intestinal microflora could have safety implications. For these gene transfer events to occur, the nucleic acid would need to survive passage through the gastrointestinal tract. The aim of the present study was to evaluate the rate at which transgenes, contained within GM soya and maize, are degraded in gastric and small bowel simulations. The data showed that $80 \%$ of the transgene in naked GM soya DNA was degraded in the gastric simulations, while no degradation of the transgenes contained within GM soya and maize were observed in these acidic conditions. In the small intestinal simulations, transgenes in naked soya DNA were degraded at a similar rate to the material in the soya protein. After incubation for $30 \mathrm{~min}$, the transgenes remaining in soya protein and naked DNA were 52 (SEM 13.1) \% and 34 (SEM 17.5) \%, respectively, and at the completion of the experiment $(3 \mathrm{~h})$ these values were $5 \%$ and $3 \%$, respectively. In contrast to the soya transgene, the maize nucleic acid was hydrolysed in the small intestinal simulations in a biphasic process in which approximately $85 \%$ was rapidly degraded, while the rest of the DNA was cleaved at a rate similar to that in the soya material. Guar gum and tannic acid, molecules that are known to inhibit digestive enzymes, did not influence the rate of transgene degradation in soya protein. In contrast guar gum reduced the rate of transgene degradation in naked soya DNA in the initial stages, but the polysaccharide did not influence the amount of nucleic acid remaining at the end of the experiment. Tannic acid reduced the rate of DNA degradation throughout the small bowel simulations, with 21 (SEM 5.4) \% and 2 (SEM $1.8) \%$ of the naked soya DNA remaining in the presence and absence of the phenolic acid, respectively. These data indicate that some transgenes in GM foods may survive passage through the small intestine.
\end{abstract}

Genetically modified foods: Intestinal degradation: Quantitative polymerase chain reaction

The recent development of technologies that enable arable crops to be genetically modified (GM) has resulted in the inclusion of GM foods in the human diet. Many of the modifications introduced into plants by this technology are designed to confer resistance to herbicides and pesticides.
Typical examples are the glyphosphate-resistant variants of soya (Padgette et al. 1995), and pesticide-tolerant maize strains that express Bacillus thurinogenesis $\delta$-toxin (Bt maize; Koziel et al. 1993). One of the major concerns in respect of GM foods is their possible threat to human

\footnotetext{
Abbreviations: bp, base pairs; Bt maize, pesticide-tolerant maize expressing Bacillus thurinogenesis $\delta$-toxin; GG, guar gum; GM, genetically modified; MM, maximizer maize; PCR, polymerase chain reaction; QC-PCR, quantitative competitive polymerase chain reaction; RRS, Roundup Ready soya; TA, tannic acid.

* Corresponding author: Professor John C. Mathers, fax +44 191 2228684, email John.Mathers@ Newcastle.ac.uk
} 
health. Some of the current GM foods contain antibiotic resistance genes, which could contribute to the spread of pathogenic micro-organisms that are immune to the antimicrobial agents currently available. In addition, there is a general concern that the transfer of plant-derived transgenes to the resident intestinal microflora could have safety implications.

Intuitively one would predict that the chance of vertical gene transfer from plants to micro-organisms in the gastrointestinal tract is extremely slight, due to the high levels of the pancreas-derived DNAase in the small intestine. This view is supported by Maturin \& Curtiss (1976) who showed that bacterial DNA was rapidly degraded in the rat intestinal tract. In contrast, mammalian DNA infused into the duodenum of calves was detected in the distal ileum (Maturin \& Curtiss, 1976). Further evidence indicating that a proportion of dietary DNA can survive passage through the gastrointestinal tract is provided by two recent studies (Schubbert et al. 1994, 1997), which showed that bacteriophage M13 DNA, fed to mice, was detected in the faeces, indicating that a proportion of the DNA survives in the gastrointestinal tract. In addition, this group detected the phage DNA in the liver demonstrating that the nucleic acid was able to pass through the intestinal epithelium into the systemic circulation. These studies cast doubt on the assumption that plant-derived transgenes will not transfer to the intestinal microflora because the nucleic acid will be rapidly and completely degraded by the digestive enzymes.

In evaluating the safety of GM foods there is need to determine the stability of the transgenes in food within the gastrointestinal tract. The objectives of the present study were to investigate (1) the rate at which two heterologous genes, present in GM soya and maize, were degraded when exposed to in vitro gastric and small intestinal simulations, and (2) how components of the diet that are known to influence intestinal function, affected this process.

\section{Material and methods}

\section{In vitro digestions}

The sources of transgenic DNA were seeds of Bt maize (Maximizer maize; MM) kindly supplied by Monsanto UK Ltd., London, and a commercial texturised soya protein containing $10 \%$ of GM herbicide (glyphosate)-resistant soyabeans (Roundup Ready soya; RRS). These were chosen as examples of GM foods consumed in the USA and in Europe. A $50 \mathrm{~g}$ sample of each food source was ground to a fine powder, checking frequently for overheating of the samples.

Guar gum (GG) and tannic acid (TA) were purchased from Sigma-Aldrich Company Ltd. (Fancy Road, Poole, Dorset, UK) and dissolved in $120 \mathrm{~mm} \mathrm{NaCl}$ to a final concentration of $8 \mathrm{mg} / \mathrm{ml}$ and $1 \mathrm{mg} / \mathrm{ml}$, respectively. The proteinase, porcine pepsin (800-2500 units/mg protein), was purchased from Sigma Chemical and used without further preparation. Ileal digesta was obtained from five ileostomised volunteers and the material subsequently lyophilised and pooled. Shortly before use, $100 \mathrm{mg}$ pepsin were dissolved in $2.5 \mathrm{ml}$ of $120 \mathrm{~mm} \mathrm{NaCl}$. Peptic and intestinal digestions were carried out in an orbital incubator.

The in vitro simulation of human digestion was modified from that used by Glahn et al. (1996). A $50 \mathrm{mg}$ sample of ground maize seeds or texturised soya protein, or naked genomic-DNA extracted from an equivalent amount of soya protein (approximately $48 \mu \mathrm{g}$ genomic DNA) was resuspended in $500 \mu \mathrm{l}$ of $120 \mathrm{~mm}-\mathrm{NaCl}, \mathrm{NaCl}$ containing $\mathrm{GG}$ and $\mathrm{NaCl}$ containing TA. To these mixtures, $\mathrm{HCl}$ and pepsin were added to final concentrations of $15 \mathrm{~mm}$ and $2 \mathrm{mg} / \mathrm{ml}$, respectively. The tubes were then capped, placed horizontally and incubated in an orbital incubator at $37^{\circ} \mathrm{C}$ and $150 \mathrm{rpm}$ for $60 \mathrm{~min}$. Once the peptic digestion was completed the $\mathrm{pH}$ was neutralized by adding $\mathrm{NaHCO}_{3}$ to a final concentration of $50 \mathrm{~mm}$ followed by $50 \mathrm{mg}$ of freeze-dried ileal digesta and $200 \mu \mathrm{l}$ of Milli-Q water to simulate intestinal digestion. Samples were incubated for 5, 10, 15, 30, 60, 120 and $180 \mathrm{~min}$ (separate tubes for each time point). At the completion of each digestion time, $800 \mu \mathrm{l}$ of $6 \mathrm{M}$ guanidine hydrochloride were added to stop enzymic activity. The capacity of this concentration of guanidine hydrochloride to inhibit enzymic degradation of DNA was tested previously (data not shown). To evaluate the degradation of transgenic DNA after digestion with pepsin- $\mathrm{HCl}$, guanidine hydrochloride was added to one reaction after $\mathrm{pH}$ neutralisation and ileal digesta was added subsequently. In the time 0 sample, all the components of the reaction, including guanidine hydrochloride, were added to the tube before the addition of the DNAcontaining material. As a negative control one tube with all the reactants except the DNA-containing material was treated in the same way as the test samples. Once the reactions had finished and been treated with guanidine hydrochloride, they were placed on ice until DNA was extracted.

Incubations of soya protein and naked DNA with and without GG or TA were always performed in the same batch. Each incubation was repeated at least twice in different experiments.

\section{Sample DNA extraction and purification}

Naked DNA from GM soya protein, used in the in vitro digestions, was extracted from $100 \mathrm{mg}$ of ground material resuspended in $400 \mu \mathrm{l}$ of water and $600 \mu \mathrm{l}$ of $6 \mathrm{M}$ guanidine hydrochloride and incubated at $58^{\circ} \mathrm{C}$ for $3 \mathrm{~h}$ with vortexing every $15 \mathrm{~min}$. The mixture was centrifuged at $13000 \mathrm{~g}$ for $10 \mathrm{~min}$ and DNA in the soluble fraction was purified from $500 \mu \mathrm{l}$ of the supernatant fraction (i.e. equivalent to half of the starting material) using the Wizard DNA clean-up system Protocol (Promega, Madison, WI, USA). The DNA was eluted in $50 \mu l$ of sterile Milli-Q water. The DNA from the in vitro pepsin- $\mathrm{HCl}$ and ileal incubations was extracted and purified following the same protocol.

\section{Primer oligonucleotides}

Primers, which were synthesised by the Central Molecular Biology Facility, University of Newcastle upon Tyne, were obtained in a lyophilized state and stored at $-20^{\circ} \mathrm{C}$. The sequences of the primers used to construct internal DNA standards and to perform quantitative competitive 
polymerase chain reactions (QC-PCR; Raeymaekers, 1993) are listed in Table 1 where italicised bases denote restriction sites.

\section{Quantitative polymerase chain reaction}

All polymerase chain reaction (PCR) amplifications were carried out on a PTC-100 Programable Thermocontroller (M.J. Research, Inc., Waltham, MA, USA). For each series of reactions, a master-mix was prepared comprising $5 \mu \mathrm{l} 10 \times \mathrm{PCR}$ buffer (Perkin Elmer, Vienna, Austria), $10 \mu \mathrm{l} 25 \mathrm{mM} \mathrm{MgCl}_{2}, 0.4 \mu \mathrm{l} 100 \mathrm{~mm}$ deoxynucleoside triphosphate mix (Gene Kraft, Germany), $0.5 \mu \mathrm{l} 25 \mathrm{~mm}$ primer, $0.25 \mu \mathrm{l}$ Amplitaq Gold Polymerase (5U/ $\mu \mathrm{l}$, Perkin Elmer, Germany), $1 \mu \mathrm{l} 1 \mathrm{mg} / \mathrm{ml}$ bovine serum albumin (Boehringer Mannheim, Germany) and 22.4 $\mu \mathrm{l}$ of water. Each reaction contained $5 \mu$ of a 1:5 dilution of the DNA purified from each sample, $5 \mu$ l of DNA competitors and $40 \mu \mathrm{l}$ of master mix. The competitor DNA, in a volume of $5 \mu \mathrm{l}$, was added at amounts ranging from $8 \times$ $10^{1}$ to $25 \times 10^{5}$ copies. As negative controls for the DNA extractions and the amplification reactions, two PCR were carried out; one contained material extracted from ileal contents that had not been incubated with GM soya or maize, the other reaction contained $10 \mu \mathrm{l}$ of water instead of DNA. After initial denaturation at $95^{\circ} \mathrm{C}$ for $7 \mathrm{~min}$, fifty cycles of denaturation at $95^{\circ} \mathrm{C}$ for $30 \mathrm{~s}$, annealing at $62^{\circ} \mathrm{C}$ for $30 \mathrm{~s}$ and extension at $72^{\circ} \mathrm{C}$ for $45 \mathrm{~s}$ were carried out, with a final extension step of $7 \mathrm{~min}$ at $72^{\circ} \mathrm{C}$. Following the PCR amplification, $15 \mu \mathrm{l}$ of each reaction mix were electrophoresed on $2 \%(\mathrm{w} / \mathrm{v})$ agarose gels, stained with ethidium bromide and visualized using a u.v. transiluminator.

\section{Construction of the internal standards}

Strategies for construction of the competitor sequence for the QC-PCR are presented in Fig. 1. The complete synthetic cryIA (b) gene was amplified from GM-maize DNA using the primers Cry01 and Cry02 described by Hupfer et al. (1998), and cloned into pCR-Blunt (Invitrogen, Leek, The Netherlands) to generate pBNS1. The 509 (bp) product, obtained from GM-soya DNA using the primers RR01 and RR02 described by Studer et al. (1998), was cloned into the vector $\mathrm{pCR} 2 \cdot 1$ (Invitrogen) to generate pBNS2. The plasmids containing the competitor DNA

PCR 1
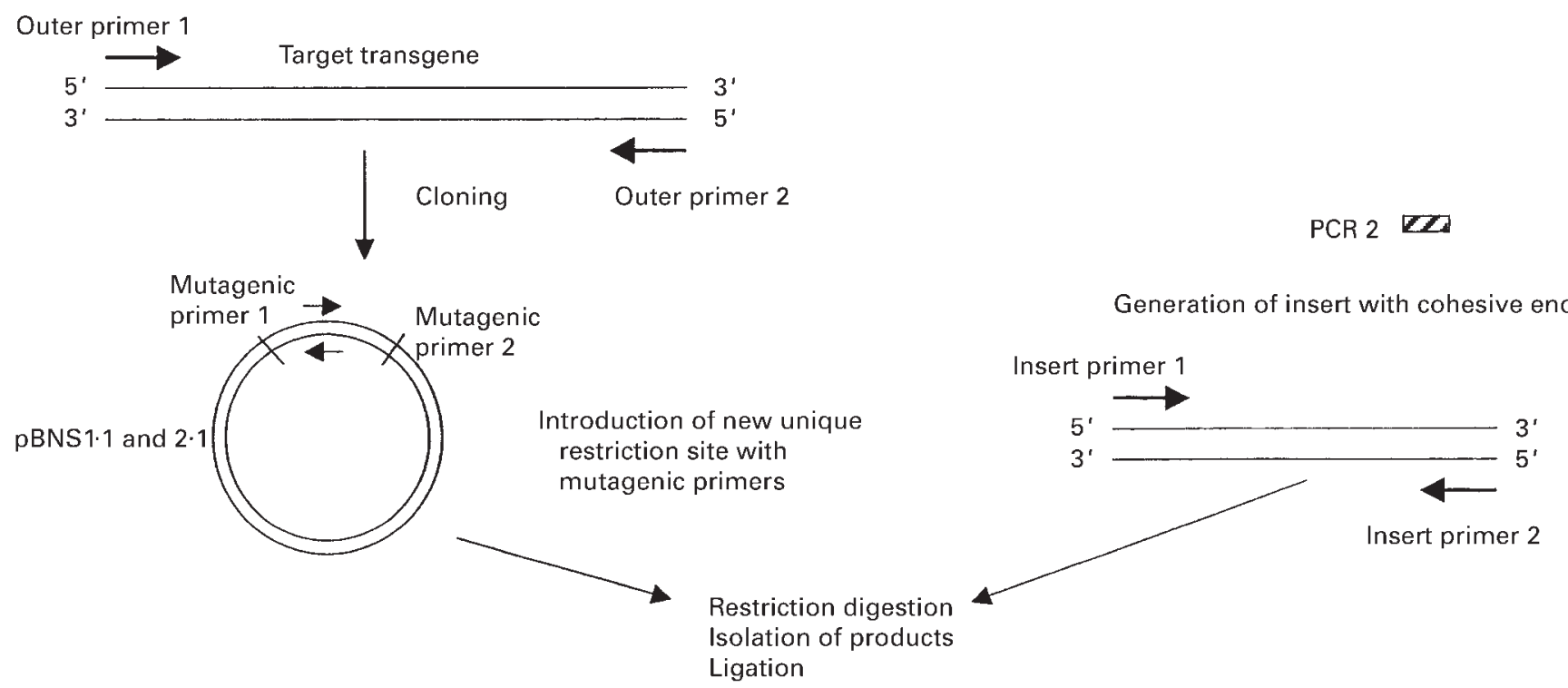

PCR $2 \not L$

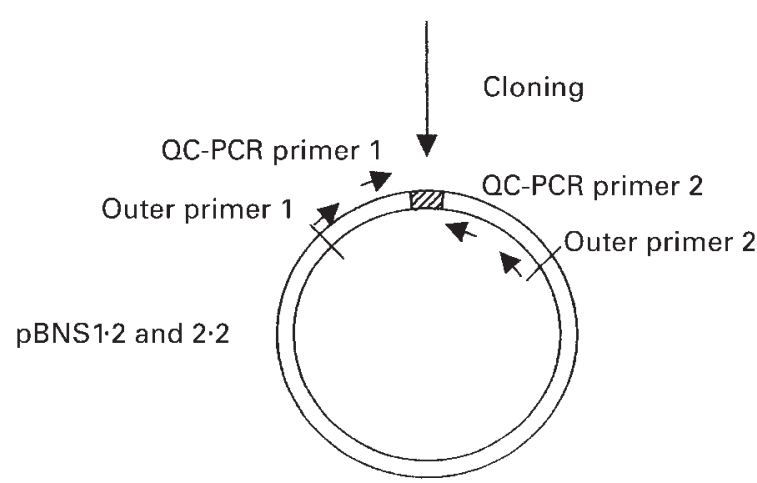

Fig. 1. Scheme for the construction of competitor for use in quantitative competitive polymerase chain reactions (QC-PCR). The primers used to amplify the transgenes and to introduce the restriction site into this sequence are listed in Table 1. The 100 base pairs (bp) sequence inserted into the soya and maize transgene were derived from pET16b and pCR-Blunt, respectively. The sequence denotes the $100 \mathrm{bp}$ insert. 
Table 1. Primers for construction of DNA standards and used in quantitative competitive polymerase chain reaction (QC-PCR)

\begin{tabular}{|c|c|c|c|c|c|}
\hline & Name & Sequence $\left(5^{\prime}-3^{\prime}\right)^{*}$ & Target DNA & Size (bp) & Reference \\
\hline \multicolumn{6}{|c|}{ To construct DNA competitiors } \\
\hline \multicolumn{6}{|c|}{ Maize } \\
\hline Outer primer & $\begin{array}{l}\text { Cry01 } \\
\text { Cry02 }\end{array}$ & $\begin{array}{l}\text { ATG GAC AAC AAC CCC AAC ATC } \\
\text { GGT CTT CAG GCC GAT CTG GTT }\end{array}$ & crylA (b) & 1914 & Hupfer et al. (1998) \\
\hline Mutagenic primer & $\begin{array}{l}\text { MTG1 } \\
\text { MTG2 }\end{array}$ & $\begin{array}{l}\text { GCC TAG CGG ACA TCA TAT GGG GCA TCT TCG GC } \\
\text { GCC GAA GAT GCC CCA TAT GAT GTC CGC TAG GC }\end{array}$ & pBNS1 & 5427 & Present study \\
\hline Insert primer & $\begin{array}{l}\text { INS1 } \\
\text { INS2 }\end{array}$ & $\begin{array}{l}\text { CAT CAT CAT ATG GCC CCA GTG CTG C } \\
\text { CAT CAT CAT ATG CGC TCG GCC CTT CCG }\end{array}$ & $\mathrm{pET} 16 \mathrm{~b}$ & 112 & Present study \\
\hline \multicolumn{6}{|c|}{ 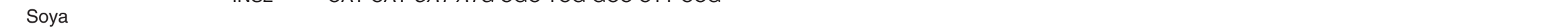 } \\
\hline Outer primer & $\begin{array}{l}\text { RR01 } \\
\text { RR02 }\end{array}$ & $\begin{array}{l}\text { TGG CGC CCA TGG CCT GCA TG } \\
\text { CCT TCG CAA GAC CCT TCC TCT ATA }\end{array}$ & $\begin{array}{l}\text { CP4 EPSPS, petunia EPSPS CTP } \\
\text { E35S promoter }\end{array}$ & 509 & Studer et al. (1998) \\
\hline Mutagenic primer & $\begin{array}{l}\text { MTG3 } \\
\text { MTG4 }\end{array}$ & $\begin{array}{l}\text { CGT GAA GCA TGC AGG CTG TCG ACA CTG ATG CTG AAA TCC } \\
\text { GGA TTT CAG CAT CAG TGT CGA CAG CCT GCA TGC TTC ACG }\end{array}$ & pBNS2 & 4416 & Present study \\
\hline Insert primer & $\begin{array}{l}\text { INS3 } \\
\text { INS4 }\end{array}$ & $\begin{array}{l}\text { CAT CAT GTC GAC CAG TGC CGT TCC GG } \\
\text { CAT CAT GTC GAC GAA GTC CCG GGA G }\end{array}$ & pCR-Blunt & 109 & Present study \\
\hline \multicolumn{6}{|l|}{ To perform QC-PCR } \\
\hline Maize & $\begin{array}{l}\text { BT1 } \\
\text { BT2 }\end{array}$ & $\begin{array}{l}\text { TCG ACA TCA GCC TGA GCC TG } \\
\text { TGG TTG ATC AGC TGC TCG ATC }\end{array}$ & crylA(b) & 151 & \\
\hline Soya & $\begin{array}{l}\text { RR04 } \\
\text { RR05 }\end{array}$ & $\begin{array}{l}\text { CCC CAA GTT CCT AAA TCT TCA AGT } \\
\text { TGC GGG CCG GCT GCT TGC A }\end{array}$ & E35S promoter petunia EPSPS CTP & 180 & Studer et al. (1998) \\
\hline
\end{tabular}

bp, base pairs; EPSPS, 5-enolpyruvylshikimate-3-phosphatesynthasse.

Italicised bases denote restriction sites. 
were generated by introducing a unique restriction site, Nde I for maize (pBNS1.1) and Sal I for soya (pBNS2·1), in the middle of each of the cloned amplicons. This was achieved using the Quick Change Site-directed Mutagenesis kit (Stratagene Europe, Amsterdam Zuidoost, The Netherlands) and the mutagenic primers listed in Table 1. Inserts comprising 100 bp flanked by either Nde I or Sal I
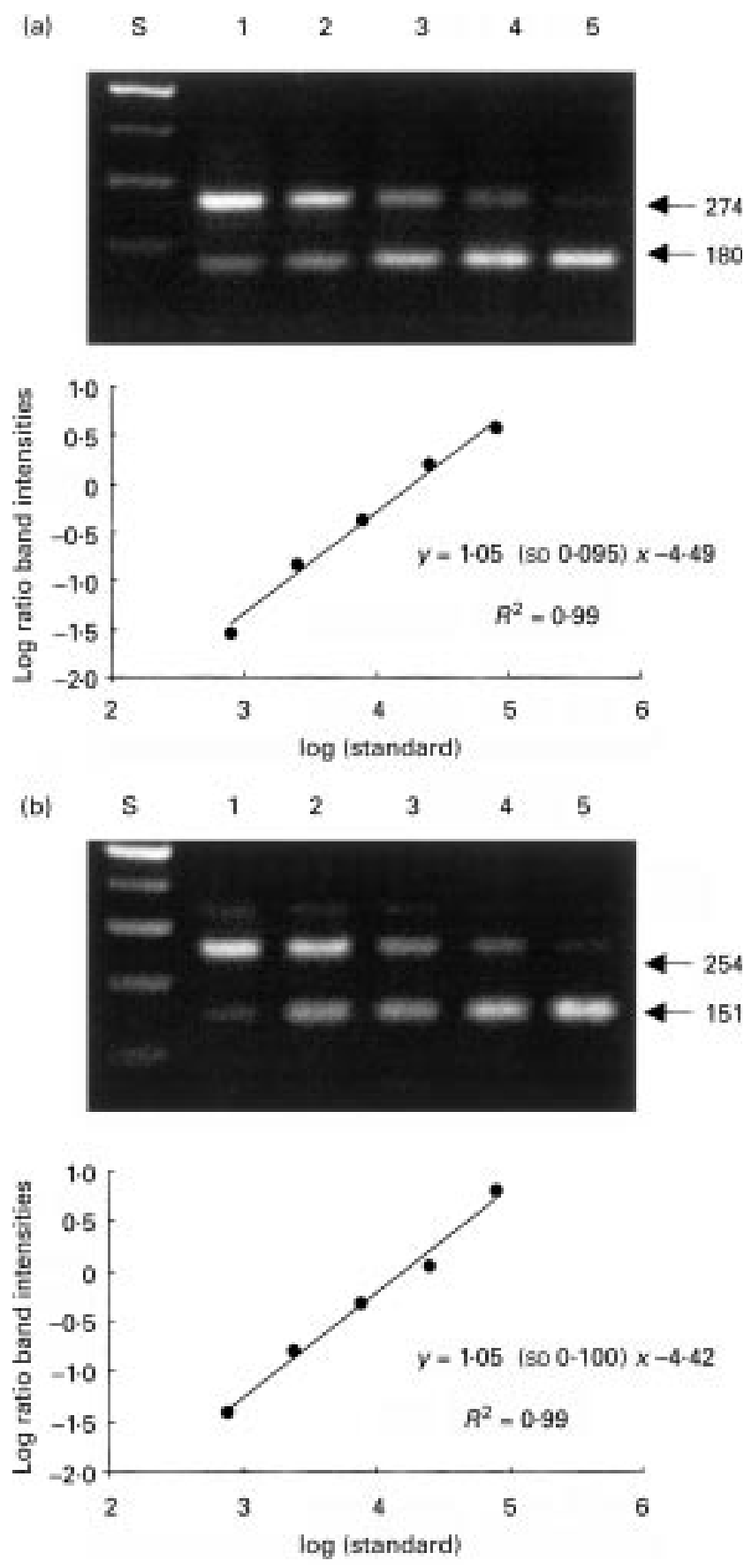

Fig. 2. Determination of transgenic DNA. Content of soya protein at time 0 of incubation (a) and maize meal incubated for $1 \mathrm{~h}$ with pepsin- $\mathrm{HCl}$ and $2 \mathrm{~h}$ with intestinal content (b). The polymerase chain reaction products were subjected to electrophoresis on a $2 \%(\mathrm{w} / \mathrm{v})$ agarose gel. Lane S 100-bp ladder, lanes 1-5 competitor added to the sample at $79 \times 10^{3}, 25 \times 10^{3}, 79 \times 10^{2}, 25 \times 10^{2}$ and 790 copies, respectively. For details, see p. 534. restriction sites were generated by PCR using primers listed in Table 1, using pET16b and pCR-blunt vectors, respectively, as DNA templates. Restricted and purified fragments, derived from the PCR, were ligated with previously restricted and dephosphorylated pBNS1.1 and pBNS2.1 (alkaline phosphatase; Boehringer MannheimRoche). Plasmids containing the inserted DNA derived from $\mathrm{pBNS} 1 \cdot 1$ and $\mathrm{pBNS} 2 \cdot 1$ were designated pBNS1.2 and $\mathrm{pBNS} 2 \cdot 2$, respectively. The plasmids $\mathrm{pBNS} 1.2$ and pBNS2.2 were isolated using the Qiagen Plasmid Midi Kit (Qiagen, Crawley, West Sussex) and sequenced. Plasmid DNA concentrations were determined by measuring $\mathrm{A}_{260}$.

\section{Quantification of polymerase chain reaction products}

Gel pictures were digitalized using a charge-coupled device camera. The intensities of the bands were determined by image processing software (Quantity ONE, version 4.0, Bio-Rad, Cambridge, UK) and corrected for their molecular weight. The equivalence point where competitor and sample DNA concentrations were the same was calculated by the linear regression between the logarithm of the ratio of corrected band intensities of the two DNA species, and the logarithm of the initial amount of target DNA. An example calculation is shown in Fig. 2.

\section{Experimental design}

Four batches of incubations containing soya protein and four with naked soya genomic DNA were carried out. In two of them, samples were incubated simultaneously with and without TA and in the other two with and without GG. For maize, four duplicates were carried out in four independent batches.

Results of degradation of transgenic soya protein and maize, and naked genomic DNA were statistically analysed using the General Linear Model in SAS (SAS Institute, 1996). Before analysis, data were log-transformed as necessary to achieve equal variance. The model used was:

$$
\begin{aligned}
\mathrm{Y}_{\mathrm{ijkl}}= & \mu+\mathrm{P}_{\mathrm{i}}+\mathrm{I}_{\mathrm{j}}+\mathrm{T}_{\mathrm{k}}+(\mathrm{P} \times \mathrm{I})_{\mathrm{ij}}+(\mathrm{P} \times \mathrm{T})_{\mathrm{ik}} \\
& +(\mathrm{P} \times \mathrm{I} \times \mathrm{T})_{\mathrm{ijk}}+\mathrm{E}_{\mathrm{ijkl}},
\end{aligned}
$$

in which $\mathrm{P}$, the protective effect of the food (soya protein $v$. naked DNA); I, the inhibitory effect of GG or TA; T, the time of incubation were considered as fixed effect factors (Sokal \& Rohlf, 1995). The residual error term derived from variation between replicates was used to test each of the fixed effect factors and their interactions.

\section{Results}

\section{Quantitative competitive polymerase chain reaction}

To detect and quantify transgenic DNA from RRS and MM in the in vitro gastric and intestinal digesta, a QC-PCR method was developed where the two competitor DNA molecules contained an extra $100 \mathrm{bp}$ of sequence. The region of the transgenes amplified from the soya and maize were 151 and $180 \mathrm{bp}$, respectively. This relatively 
small size was chosen because it increases the sensitivity of the method as PCR are more efficient at amplifying short sequences of DNA, particularly where fragmentation of the DNA is expected to be high. The primers BT1 and BT2 amplified a fragment of the synthetic cryIA(b) gene introduced into maize, while the RR04 and RR05 primers amplified a fragment of the transgene inserted into the soya genome comprising regions of the CP4 5enolpyruvylshikimate-3-phosphatesynthase gene from Agrobacterium sp. strain CP4 and the 5-enolpyruvylshikimate-3-phosphatesynthase Petunia CTP gene. To confirm that the DNA amplified by the QC-PCR comprised the target sequence, the PCR product was sequenced directly using the primers BT1 and BT2, and RR04 and RR05 for the maize- and soya-derived transgenes, respectively. The data (not shown) revealed that the amplified DNA contained the appropriate sequence, confirming that the QCPCR amplified the target transgenes. To ensure that no false positive PCR products, due to contamination of reagents or extraction buffers with target DNA, were detected, two negative controls were carried out, neither of which generated a PCR product in any of the assays performed.

An example of the quantification method for each of the transgenes is shown in Fig. 2. The validity of the two detection systems is indicated by the high regression coefficient value $\left(r^{2}\right)$, which was $>0.99$, and the slope of the regression line that was close to unity. To further validate the QC-PCR method, the linearity of the system was tested by using DNA derived from 50 or $5 \mathrm{mg}$ of soya or maize in the QC-PCR. The data showed that the total copy number for each sample was $21 \times 10^{6}$ and $25 \times 10^{5}$ for soya and $10 \times 10^{7}$ and $9 \times 10^{6}$ for maize, for 50 and $5 \mathrm{mg}$ respectively. The detection limit of the assay was assessed by performing PCR on serial dilutions of the competitors. For both systems approximately eighty copies of the transgene could be detected clearly. Given that $>100000$ copies of the transgenes were present at time 0 , the QC-PCR could detect down to about $0.08 \%$ of added transgenic DNA.

\section{Incubation of DNA with pepsin- $\mathrm{HCl}$}

The GM foods were incubated with the gastrointestinal simulations, without any additional treatments, to investigate protection of the DNA by the food matrices. To study the persistance of naked DNA in gastric and smallintestinal environments, nucleic acid extracted from the RRS was used as the source material. Prior to incubation under the simulated gastrointestinal conditions, the total amount of transgene present in these samples was determined. RRS contained approximately 10 -fold less transgene per mg DNA than did MM maize. This is likely to reflect the source of the material. RRS was purchased from supermarkets and is thus a blended product containing only a small proportion of transgenic material. In contrast, maize seeds were obtained directly from Monsanto and were completely transgenic.

The size of DNA extracted from soya and maize were quite different. The maize nucleic acid was of high molecular weight while the soya-derived material had been extensively fragmented, and had a molecular weight that ranged from 100 to $1000 \mathrm{bp}$. The low molecular weight of the soya DNA is likely to be the result of extensive

Table 2. Degradation of transgenic DNA from soya or naked genomic-DNA incubated in vitro with pepsin- $\mathrm{HCl}$ with $(+\mathrm{GG})$ or without $(-\mathrm{GG})$ guar gum and with $(+\mathrm{TA})$ or without $(-\mathrm{TA})$ tannic acid as potential DNA protectors*

\begin{tabular}{|c|c|c|c|c|c|c|}
\hline \multirow[b]{2}{*}{ Time (min) } & \multicolumn{2}{|c|}{ Soya } & \multicolumn{2}{|c|}{ Naked DNA } & \multicolumn{2}{|c|}{ Statistics } \\
\hline & $-G G$ & $+G G$ & $-G G$ & $+G G$ & Effect & Significance \\
\hline Initial & $5 \cdot 34$ & $5 \cdot 26$ & 4.98 & 5.08 & $\mathrm{P}$ & $\dagger$ \\
\hline \multirow{8}{*}{$\begin{array}{l}\text { Digested } \\
\text { RSD }=0.422\end{array}$} & $5 \cdot 26$ & $5 \cdot 34$ & $4 \cdot 18$ & 4.49 & 1 & NS \\
\hline & & & & & & \\
\hline & & & & & $1 \times T$ & NS \\
\hline & & & & & $P \times I$ & NS \\
\hline & & & & & $\mathrm{P} \times \mathrm{T}$ & $\dagger$ \\
\hline & & & & & $P \times I \times T$ & NS \\
\hline & \multicolumn{2}{|c|}{ Soya } & \multicolumn{2}{|c|}{ Naked DNA } & \multicolumn{2}{|c|}{ Statistics } \\
\hline & $-\mathrm{TA}$ & $+\mathrm{TA}$ & $-\mathrm{TA}$ & $+\mathrm{TA}$ & Effect & Significance \\
\hline Initial & $5 \cdot 26$ & $4 \cdot 81$ & $4 \cdot 29$ & $4 \cdot 12$ & $P$ & ††† \\
\hline \multirow[t]{3}{*}{ Digested } & $5 \cdot 29$ & 4.79 & 3.67 & 3.86 & I & $t$ \\
\hline & & & & & T & $\dagger$ \\
\hline & & & & & $I \times T$ & NS \\
\hline \multirow{3}{*}{$\mathrm{RSD}=0.193$} & & & & & $P \times 1$ & $\dagger$ \\
\hline & & & & & $\mathrm{P} \times \mathrm{T}$ & $\dagger$ \\
\hline & & & & & $P \times I \times T$ & NS \\
\hline
\end{tabular}

$\mathrm{P}$, protective effect of the food (soya $v$. naked DNA); I, inhibitory effect of GG or TA; T, time of incubation effect.

* Tabulated data are log of copies of the target sequence detected by quantitative competitive polymerase chain reaction. Each polymerase chain reaction included the DNA extracted from $0.3 \mathrm{mg}$ of soya or the equivalent naked genomic-DNA.

$\dagger P<0.05 ; \dagger \dagger+P<0.001$. 
processing to generate the soya protein product (KeShun, 1999). The incubation of RRS and MM with pepsin- $\mathrm{HCl}$ did not result in a significant decrease in transgene DNA (Table 2). In contrast, when naked DNA was incubated in the stomach simulations there was a large decrease in the amount of transgene DNA with approximately $80 \%$ of the material being degraded. This degradation was not specific to the transgenes as ethidium bromide staining of extracted DNA showed that less total DNA was present after incubation in pepsin- $\mathrm{HCl}$.

\section{Incubation of DNA with ileal digesta}

The degradation of GM food-derived DNA in the ileal samples was evaluated by agarose gel electrophoresis of total DNA extracted from the incubations, and by the quantification of transgenic DNA using QC-PCR. The data, presented in Table 3 and Fig. 3, showed that there was progressive degradation of total DNA and the transgenes. Surprisingly, the naked soya DNA was degraded at a rate similar to the transgene in the RRS; after incubation for $30 \mathrm{~min}$ the transgenes remaining in RRS and naked DNA were 52 (SEM 13.1) and 34 (SEM 17.5) \%, respectively. At the completion of the experiment, after soya protein and naked soya DNA had been incubated with ileal digesta for $3 \mathrm{~h}$, approximately $5 \%$ and $3 \%$, respectively, of the transgenes (present at the start of the ileal incubations) could still be detected. These data suggest that the food stuff protected DNA against degradation in acidic conditions, but not against digestive enzymes in the small intestine. In contrast to soya DNA, the degradation of the maize nucleic acid in the smallintestinal simulation was a biphasic process in which approximately $85 \%$ was rapidly degraded, while the rest of the DNA was cleaved at a rate similar to that for the transgene in soya (Table 3 ).

\section{Effects of tannic acid and guar gum on DNA degradation}

To investigate the influence of other components of food on the rate of degradation of the transgenes in the intestines, GG and TA were included in the incubations (Table 3). Addition of GG to the incubations did not result in a detectable change in the rate of DNA degradation from soya protein. However, surviving transgenicDNA was higher in samples of naked-genomic DNA in which GG was added (interaction $\mathrm{P} \times \mathrm{I}, \quad P=0 \cdot 12$; Table 3). This protective effect was apparent only in the initial stages of the incubations (up to $30 \mathrm{~min}$ ). The amount of DNA remaining at the end of the experiment (180 min) was approximately $3 \%$ and independent of whether GG was added.

The effect of TA on DNA integrity was different between the nucleic acid in soya-protein and the naked genome (interaction $\mathrm{P} \times \mathrm{I}, P<0.001$; Table 3). TA promoted a higher apparent rate of degradation of transgenic DNA from RRS which remained constant with time of incubation. In contrast, the rate of naked DNA cleavage was lower when TA was included in the incubations, with differences ranging from $10^{0 \cdot 2}$ to $10^{1 \cdot 6}$ dependent on

Table 3. Degradation of transgenic DNA from soya or naked genomic-DNA incubated in vitro with intestinal enzymes for $5-180$ min with $(+G G)$ or without $(-G G)$ addition of guar gum and with $(+\mathrm{TA})$ or without $(-\mathrm{TA})$ tannic acid as potential DNA protectors*

\begin{tabular}{|c|c|c|c|c|c|c|}
\hline \multirow[b]{2}{*}{ Time (min) } & \multicolumn{2}{|c|}{ Soya } & \multicolumn{2}{|c|}{ Naked DNA } & \multicolumn{2}{|c|}{ Statistics } \\
\hline & $-G G$ & $+G G$ & $-G G$ & $+\mathrm{GG}$ & Effect & Significance \\
\hline 0 & $5 \cdot 26$ & $5 \cdot 34$ & $4 \cdot 18$ & 4.49 & $\mathrm{P}$ & ††† \\
\hline 5 & $5 \cdot 27$ & $5 \cdot 25$ & 4.17 & 4.57 & I & NS \\
\hline 10 & 5.00 & 4.97 & 3.81 & 4.44 & $\mathrm{~T}$ & ††† \\
\hline 15 & $5 \cdot 14$ & 5.29 & 3.89 & 4.41 & $\mathrm{I} \times \mathrm{T}$ & NS \\
\hline 30 & $4 \cdot 87$ & 4.94 & $3 \cdot 66$ & 4.38 & $P \times I$ & NS \\
\hline 60 & 4.73 & 4.69 & 3.51 & 4.14 & $P \times T$ & NS \\
\hline 120 & 3.95 & 4.09 & $2 \cdot 79$ & 3.52 & $P \times I \times T$ & NS \\
\hline \multirow[t]{3}{*}{180} & 3.80 & 3.84 & 2.35 & $2 \cdot 83$ & $\mathrm{RSD}=0.601$ & \\
\hline & \multicolumn{2}{|c|}{ Soya } & \multicolumn{2}{|c|}{ Naked DNA } & \multicolumn{2}{|c|}{ Statistics } \\
\hline & $-\mathrm{TA}$ & $+\mathrm{TA}$ & $-\mathrm{TA}$ & $+\mathrm{TA}$ & Effect & Significance \\
\hline 0 & 5.29 & 4.79 & 3.67 & 3.86 & $\mathrm{P}$ & ††† \\
\hline 5 & $5 \cdot 29$ & $4 \cdot 76$ & 3.48 & 4.03 & I & $\dagger \dagger$ \\
\hline 10 & $5 \cdot 21$ & 4.63 & $3 \cdot 27$ & 4.03 & $\mathrm{~T}$ & ††† \\
\hline 15 & $5 \cdot 29$ & $4 \cdot 78$ & $3 \cdot 21$ & 3.99 & $I \times T$ & NS \\
\hline 30 & 5.06 & 4.60 & 2.92 & 3.76 & $P \times I$ & ††† \\
\hline 60 & $4 \cdot 77$ & $4 \cdot 32$ & $2 \cdot 80$ & 3.46 & $P \times T$ & NS \\
\hline 120 & $4 \cdot 26$ & 3.91 & 1.98 & 3.20 & $P \times 1 \times T$ & NS \\
\hline 180 & 3.99 & 3.52 & 1.62 & 3.17 & $\mathrm{RSD}=0.246$ & \\
\hline
\end{tabular}

$P$, protective effect of the food (soya $v$. naked DNA); I, inhibitory effect of GG or TA; T, time of incubation effect.

* Tabulated data are log of copies of the target sequence detected by quantitative competitive polymerase chain reaction. Each polymerase chain reaction included the DNA extracted from $0.3 \mathrm{mg}$ of soya or the equivalent naked genomic-DNA.

$\dagger \uparrow P<0.01 ;$ ††† $P<0.001$ 
[a)

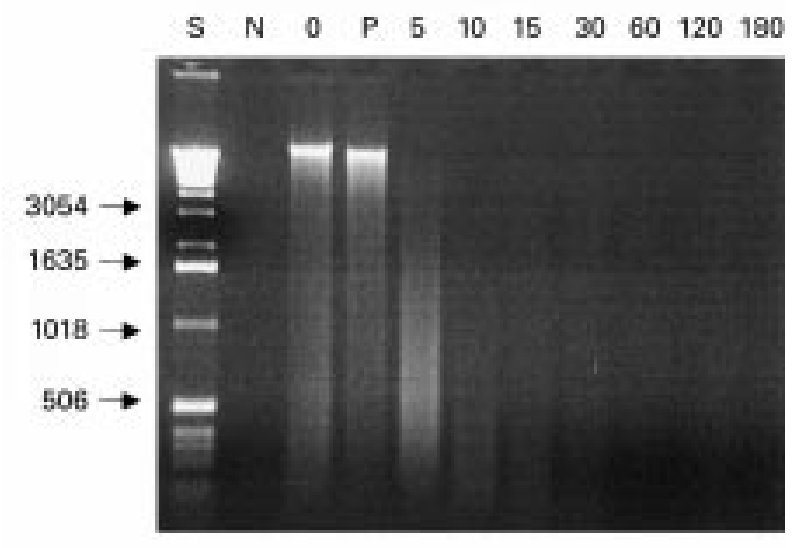

(b)

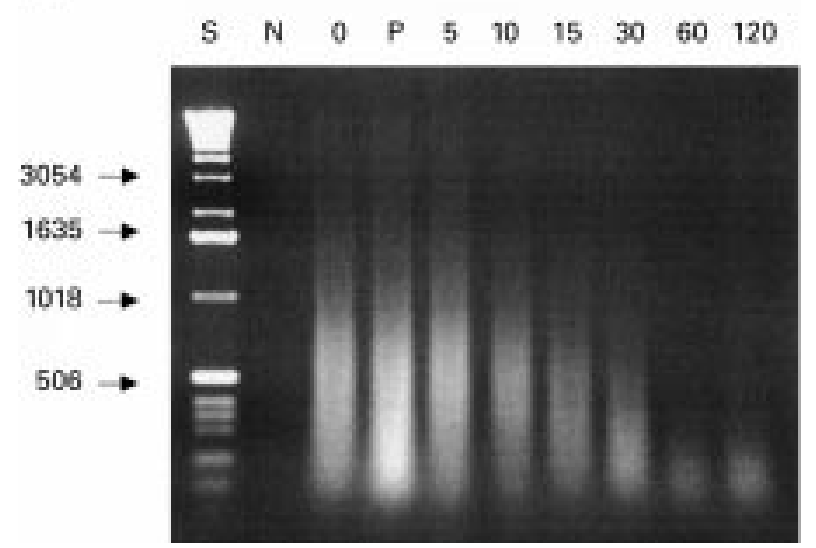

Fig. 3. Degradation of maize and soya DNA. Maize (a) or soya DNA (b) was incubated for $1 \mathrm{~h}$ with pepsin- $\mathrm{HCl}(\mathrm{P})$ and subsequently for $5,10,15,30,60,120$ and $180 \mathrm{~min}$ with ileal digesta. DNA was separated by electrophoresis on a $1 \%(\mathrm{w} / \mathrm{v})$ agarose gel using $10 \mu \mathrm{l}$ samples. A $1 \mathrm{~kb}$ ladder (S) was used as marker and 0 is the DNA at time zero of incubation. For details, see p. 534.

the time of incubation. Naked genomic-DNA nucleic acid remaining after $180 \mathrm{~min}$ of incubation was 11.2 (SEM 1.65 ) $\%$ when TA was included compared with 0.4 (SEM $0.23) \%$ in its absence. When values of surviving DNA were compared with the DNA that resisted gastric simulation, percentages of degradation were 20.8 (SEM 3.1) and 2.4 (SEM 1.8) \% when genomic-DNA was incubated with ileal digesta in the presence or absence of TA respectively.

\section{Discussion}

The objective of the present study was to evaluate the extent to which transgenes in GM foods can survive in the upper gastrointestinal tract. Such information is important when assessing the perceived risk that gene transfer from GM foods to the intestinal microflora could have on human health. In our study we have used two GM foods, MM and RRS, that are freely available to the general public, and QC-PCR to determine the survival of the transgenes. In assessing the validity of the PCR methodology used in the present study, the possible contamination of the samples with minute traces of experimental DNA (especially at the end of the incubations) was investigated by including two negative controls in each batch of incubations, extractions, purifications and PCR. No DNA was detected in the negative controls indicating that the DNA detected was not due to contamination.

The present study shows that naked DNA was extensively degraded in the simulated acid stomach, consistent with the view that acid conditions mediate extensive depurination of nucleic acid (Raw, 1983). In contrast, the nucleic acid in soya protein and maize seeds did not appear to be affected by the acidic conditions, suggesting that the DNA contained within these foods was resistant to depurination. It is possible that the food matrix, in some way, had a buffering effect such that the proton concentration in the micro-environment of the DNA was not as high as in the bulk of the reaction.

Mammalian DNAases from the small bowel have $\mathrm{pH}$ optima in the range 4.5-7.7 (Nakayama et al. 1981; Nagae et al. 1982; Anai et al. 1983) and so should have been active at the neutral $\mathrm{pH}$ used in the digestion model used in the present study. Degradation of DNA in both maize and soya protein occurred in the small-intestinal simulations, but approximately 4.5 and $0.5 \%$ of soya and maize DNA, respectively, survived after $3 \mathrm{~h}$ of these incubations. The kinetics of DNA degradation were different for the two foods; the MM nucleic acid was hydrolysed in a biphasic process, while DNA in the RRS decreased exponentially. These data suggest that the maize DNA existed in two forms; a component that was particularly susceptible to degradation, with the remaining material extensively protected against DNAase action. It is likely that protection of the DNA to enzyme attack is mediated by its encapsulation within the maize cells, with the nucleic acid becoming available for degradation only as the plant cell wall is ruptured. If this hypothesis is tenable, then it is likely that a component of the maize seeds has been disrupted such that the intestinal DNAase can access the DNA contained within these seeds. In contrast, the RRS has already been extensively processed (KeShun, 1999), and the more uniform structure of this food product may explain the uniform sensitivity of the nucleic acid to DNAase attack. Given the extent of processing that led to the production of soya protein, it might be expected that the DNA in this material would be more sensitive to DNAase action than the maize nucleic acid. It would appear, therefore, that the soya processing did not significantly disrupt cell wall structure and thus the plant cell wall could continue to act as an effective barrier to DNA degradation by intestinal enzymes. However, if accessibility was the major factor limiting DNA degradation in the GM foods, it is somewhat surprising that naked soya DNA was hydrolysed, in the small-intestinal simulations, at a rate similar to the nucleic acid in the RRS and the bulk of the MM. A possible explanation for these data is that the depurination of the naked nucleic acid in the pepsin- $\mathrm{HCl}$ incubations destroyed the DNA that was particularly susceptible to DNAase attack, i.e. about $85 \%$ of the material. The remaining $15 \%$ of DNA may have been extensively modified within the soya seeds, such that it was resistant to acid and enzyme attack. Modifications 
could include very tight association with histones within the highly structured heterochromatin regions of the genome. The heterochromatin structure may not have been disrupted during DNA purification, and would thus be present in the naked DNA used in these experiments. Alternatively, the DNAase-resistant DNA may comprise hypermethylated regions of the nucleic acid, as such regions may be resistant to both depurination and enzymic degradation.

There are very few studies that have investigated the fate of foreign DNA ingested with food in the gastrointestinal tract. Monitoring the fate of naked DNA (thymus) infused into the duodenum of calves showed that only $3 \%$ was detected in the distal ileum (McAllan, 1980). Similarly Maturin \& Curtiss (1976) reported that rat small-intestinal contents rapidly degraded bacterial naked DNA with only $0.1 \%$ of DNA remaining after $4 \mathrm{~h}$. These authors also showed that the DNA was degraded much more slowly in the rat large bowel contents, although these assays were not carried out under the anaerobic conditions necessary to ensure viability of anaerobic bacteria which dominate the large bowel. In the Maturin \& Curtiss (1976) study, similar results were obtained when the intestinal contents from gnotobiotic and conventional rats were used, suggesting that, under the conditions of their studies, DNA degradation was caused by mammalian enzymes and not microbial DNAases. More recently Schubbert et al. (1994) fed M13 bacteriophage DNA to mice and could detect, by dot-blot hybridization, about $2-4 \%$ of the administered DNA in the faecal excretions of mice $1-7 \mathrm{~h}$ after feeding. They also detected about $5 \%$ of the phage DNA after incubation with rat intestinal contents in vitro for $8 \mathrm{~h}$. A further study by Schubbert et al. (1997) reported that $95 \%$ of naked phage DNA was degraded after gastric passage, and $0.7-2.2 \%$ of the nucleic acid remained in the small intestine $1-8 \mathrm{~h}$ after feeding. Notwithstanding differences in methodology between these studies, these data suggest that eukaryotic DNA may survive longer in the gastrointestinal tract than prokaryotic-derived nucleic acid. It is possible that the hypermethylation of plant and mammalian DNA, its tight association with histones, and, especially for plant DNA, the protection against ingress of DNAases afforded by the cell wall may provide more protection against DNAase attack than is the case with prokaryotic DNA.

In addition to measuring DNA degradation per se, the present study was also designed to evaluate how components in the human diet could influence DNA degradation. The two food sources evaluated were TA and GG. GG is a soluble galactomannan non-starch polysaccharide used widely as a stabiliser and for other technological reasons in many foods. It was chosen as a potential protector of the DNA as it has been reported to retard the digestion and absorption of several nutrients (Cameron-Smith et al. 1994; Ehrlein \& Stockmann, 1998). TA is a phenolic compound present in numerous foods including green beans, lentils, tea and coffee and is also used as a food additive. It was selected because of its ability to form complexes with proteins including digestive enzymes (Horigome et al. 1988), inhibiting their activity (Quesada et al. 1996). TA has also been reported to bind strongly to DNA (Khan et al. 2000) and this prop- erty could, potentially, confer protection to the DNA. The data showed that GG protected naked DNA from degradation during the initial stages of the incubations, but not the nucleic acid in the soya protein. These results are consistent with the capacity of GG to inhibit the action of digestive enzymes. That GG did not protect against nucleic acid degradation in soya protein suggests that the major factor limiting cleavage of this DNA is the integrity of the food matrix, which was not influenced by this polysaccharide.

TA reduced the rate at which naked DNA was degraded, and this protective effect continued throughout the incubation. It is likely that TA mediates its effect by binding to both DNAase directly, thus reducing its catalytic activity, and to DNA making it less available to attack from the intestinal digestive enzymes. In contrast, TA appeared to increase the rate at which DNA in RRS was degraded. The decrease observed in the amount of transgenic DNA after the addition of TA, particularly at time 0 , could be due to a reduction in the efficiency of extraction of DNA from these samples. To examine this possibility, the influence of TA on the extraction process was tested by extracting nucleic acid from samples of soya protein and naked genomic-DNA in the presence and absence of the acid. The data (not shown) showed that TA did not affect the extraction process.

Important unresolved questions emanating from the present study include how much of the surviving transgene DNA will be available to intestinal bacteria and whether any of this residual transgenic DNA is taken up by commensal bacteria or by gut epithelial cells. Although it is likely that a high percentage of the DNA will remain intact within unbroken cells in food particles, or will bind strongly to macromolecular complexes, it is probable that much of the nucleic acid will be released during the fermentation of the food residues in the colon. This process takes several hours involving a consortium of prokaryotic enzymes, which degrade plant cell walls (Mathers, 1991) making accessible, at least in part, the DNA, which could then be available for uptake by micro-organisms or colonocytes. While simple juxtaposition of DNA and cells does not lead automatically to incorporation of the DNA into the cellular genome, there is evidence that exogenous DNA can be taken up by bacteria of the intestinal tract (Mercer et al. 1999).

\section{Conclusions}

The present study showed, as predicted, that naked DNA was rapidly degraded in the in vitro gastrointestinal simulations. However, transgenic DNA could be detected readily by QC-PCR at the end of each incubation. Several factors were shown to have an effect on the degradability of the DNA. The food matrix protected the DNA from digestion and GG afforded some protection to naked DNA extracted from soya. TA also increased the survival of naked genomic DNA in the small-intestinal simulations.

The results from these in vitro simulations of intestinal digestion suggest that some transgene DNA may survive in the human stomach and small bowel for up to $4 \mathrm{~h}$ and provide insights into some dietary factors that affect the 
digestion of DNA in the gastrointestinal tract. It should be noted that the QC-PCR assay used in the present study employed relatively short target sequences and leaves open the possibility that, while transgene DNA survived for a considerable period under these simulated gut conditions, the DNA may be in such small fragments as to be of limited biological significance and thus may represent no apparent health risk. However this conclusion should be treated with some caution because, using primers which amplify the complete transgene, we have detected PCR products (albeit at low levels) in digesta from a human feeding study ( $\mathrm{T}$ Netherwood, S Gockling, J Graham, AG O'Donnell, HJ Gilbert and JC Mathers, unpublished results). Future studies will be needed to determine the stability or otherwise of transgene DNA in vivo and also its persistance in the large bowel. In any event, the data from our study support the hypothesis that a proportion of transgene DNA can survive passage through the small intestine, and would therefore be available for uptake by the intestinal microflora or intestinal epithelial cells. In the light of these results the possibility that plant transgenes could be transferred to the human intestinal microflora should be considered.

\section{Acknowledgements}

This work has been funded by contracts from the MAFF (no. FSO225) and from the Food Standards Agency (no. G01008). We thank Dr Anna Barcelò for assisting in the DNA analysis.

\section{References}

Anai M, Muta A, Umeno M \& Sasaki M (1983) Purification and properties of an acid deoxyribonuclease from rat small intestinal mucosa. Journal of Biochemistry (Tokyo) 94, 339-344.

Cameron-Smith D, Collier GR \& O'Dea K (1994) Effect of soluble dietary fibre on the viscosity of gastrointestinal contents and the acute glycaemic response in the rat. British Journal of Nutrition 71, 563-571.

Ehrlein H \& Stockmann A (1998) Absorption of nutrients is only slightly reduced by supplementing enteral formulas with viscous fiber in miniature pigs. Journal of Nutrition 128, 2446-2455.

Glahn RP, Wein EM, VanCampen DR \& Miller DD (1996) Caco2 cell iron uptake from meat and casein digests parallels in vivo studies: Use of a novel in vitro method for rapid estimation of iron bioavailability. Journal of Nutrition 126, 332-339.

Horigome T, Kumar R \& Okamoto K (1988) Effect of condensed tannins prepared from leaves of fodder plants on digestive enzymes in vitro and in the intestine of rats. British Journal of Nutrition 60, 275-285.

Hupfer C, Hotzel H, Sachse K \& Engel K-H (1998) Detection of the genetic modification in heat-trated products of Bt maize by polymerase chain reaction. Zeitschrift für Lebensmittel, Untersuchung und Forschung A (Food Research and Technology) 206, 203-207.

KeShun L (1999) Soybeans, Chemistry Technology and Utilization. Gaithersburg, MD: Aspen Publishers, Inc.
Khan NS, Ahmad A \& Hadi SM (2000) Anti-oxidant, pro-oxidant properties of tannic acid and its binding to DNA. Chemico-Biological Interactions 125, 177-189.

Koziel MG, Beland GL, Bowman C, Carozzi NB, Crenshaw R, Crossland L, Dawson J, Desai N, Hill M, Kadwell S, Launis K, Lewis K, Maddox D, McPherson K, Meghji MR, Merlin E, Rhodes R, Warren GW, Wright M \& Evola SV (1993) Field performance of elite transgenic maize plants expressing an insecticidal protein derived from Bacillus thuringiensis. Bio-Technology 11, 194-200.

McAllan AB (1980) The degradation of nucleic acids in, and the removal of breakdown products from, the small intestines of steers. British Journal of Nutrition 44, 99-112.

Mathers JC (1991) Digestion of non-starch polysaccharides by non-ruminant omnivores. Proceedings of the Nutrition Society 50, $161-172$.

Maturin L \& Curtiss R (1976) Degradation of nucleic acid by nucleases in intestinal tract of rats. Science 196, 216-218.

Mercer DK, Scott KP, Bruce-Johnson WA, Glover LA \& Flint HJ (1999) Fate of free DNA and transformation of the oral bacterium Streptococcus gordonii DL1 by plasmid DNA in human saliva. Applied and Environmental Microbiology 65, 6-10.

Nagae S, Nakayama J, Nakano I \& Anai M (1982) Purification and properties of a neutral endodeoxyribonuclease from rat small intestinal mucosa. Biochemistry 21, 1339-1344.

Nakayama J, Fujiyoshi T, Nakamura M \& Anai M (1981) Purification and properties of an endodeoxyribonuclease from nuclei of bovine small intestinal mucosa. Journal of Biological Chemistry 256, 1636-1642.

Padgette SR, Kolacz KH, Delannay X, Re DB, Lavallee BJ, Tinius CN, Rhodes WK, Otero YI, Barry GF, Eichholtz DA, Peschke VM, Nida DL, Taylor NB \& Kishore GM (1995) Development, identification, and characterization of a glyphosate-tolerant soybean line. Crop Science 35, 1451-1461.

Quesada C, Bartolomé B, Nieto O, Gómez-Cordovés C, Hernández T \& Estrella I (1996) Phenolic inhibitors of $\alpha$-amylase and trypsin enzymes by extracts from pears, lentils and cocoa. Journal of Food Protection 59, 185-192.

Raeymaekers L (1993) Quantitative PCR: theoretical considerations with practical implications. Analytical Biochemistry 214, 582-585.

Raw JD (1983) Biochemistry. p. 358. New York: Harper and Row Publishers, Inc.

SAS Institute (1996) SAS ${ }^{\circledR}$. Cary, NC: SAS Institute Inc.

Schubbert R, Lettmann C \& Doerfler W (1994) Ingested foreign (phage M13) DNA survives transiently in the gastrointestinal tract and enters the bloodstream of mice. Molecular and General Genetics 242, 495-504.

Schubbert R, Renz D, Schmitz B \& Doerfler W (1997) Foreign (M13) DNA ingested by mice reaches peripheral leukocytes, spleen, and liver via the intestinal wall mucosa and can be covalently linked to mouse DNA. Proceedings of the National Academy of Sciences of the United States of America 94, 961-966.

Sokal RR \& Rohlf FJ (1995) Biometry, the Principles and Practice of Statistics in Biological Research. New York: Freeman.

Studer E, Rhyner C, Lüthy J \& Hübner P (1998) Quantitative competitive PCR for the detection of genetically modified soybean and maize. Zeitschrift für Lebensmitte, Untersuchung und Forschung A (Food Research and Technology) 207, $207-213$. 